\title{
Attitudes of Malaysian Extension Workers Towards Sustainable Agricultural Practices
}

\author{
${ }^{1}$ Neda Tiraieyari, ${ }^{1}$ Azimi Hamzah, ${ }^{1}$ Bahaman Abu Samah and ${ }^{2}$ Jegak Uli \\ ${ }^{1}$ Institute for Social Science Studies, University Putra Malaysia, Malaysia \\ ${ }^{2}$ Faculty of Defence Studies and Managmnet, National Defense University of Malaysia, Malaysia
}

Received 2012-09-29, Revised 2012-11-29; Accepted 2013-03-19

\begin{abstract}
The challenge of producing enough food for growing population increasingly affected Malaysian agricultural sector. Intensive farming system and increase in fertilizer used by farmers has led the agricultural sector to some environmental damage. The Department of Agriculture (DOA) has earmarked Sustainable Agricultural Practices (SAP) to transfer unsustainable agriculture into a sustainable manner. The SAP should be transferred by extension workers to the farmers. However little is known about Malaysian extension workers' attitudes towards SAP. Front line extension workers in the DOA were surveyed to identify their attitudes on SAP. A descriptive research design was used to collect data from 400 extension workers. Results revealed that extension workers have positive attitudes on SAP concepts. It is recommended to find out to what extent extension workers attitudes has played significant role to transfer information to the farmers.
\end{abstract}

Keywords: Attitude, Extension Worker, Sustainable Agriculture Practices

\section{INTRODUCTION}

The challenge of producing enough food has embarked Malaysia on an insensitive farming system and consequently environmental damage (Barrow et al., 2009). Mineral fertilizers account for more than $90 \%$ of fertilizers used by all types of farming systems in Malaysia. Recently sustainable agriculture practices have implemented in this country to transform the agricultural sector into sustainable manner. According to the USDA's Sustainable Agriculture Research and Education (SARE) program, sustainable agriculture promotes environmental stewardship, generates an acceptable level of income and maintains stable farm families and communities (SARE, 2003). Similarly Williams (2000) defined economically sound, environmentally protective and socially acceptable as three components of sustainable agriculture. Positive efforts made by the government agencies to minimize chemical fertilizers and use the resource on a sustainable base. Practices such as Good Agricultural Practices (GAP) and Organic Farming (OF) are being promoted by the Department of Agriculture (DOA) in order to reduce fertilizers for crop production (Tiraieyari and Uli, 2011). Although the current Malaysian agricultural policies are compatible with the standard of sustainable agriculture, however agricultural practices in the country differ to some extent from sustainability. Reaching toward sustainable agriculture is the responsibility of all participants in the system, including extension workers. The success of sustainable agricultural program depends to a large extend on training of farmers by extension workers. Thus agricultural extension workers as a source of information play an important role for achievement of sustainability by influencing farmers' adoption of Sustainable Agricultural Practices (SAP). Agunga (1995) reported extension workers should be convinced of the value of sustainability, otherwise how they can be expected to educate farmers on the concepts. Attitudes are important determinants of human behaviors; they provide direction and purpose to behavior and performance (Liaghati et al., 2008). Extension workers attitudes towards the concepts of sustainable agriculture are fundamental in building a strong sustainable agriculture Corresponding Author: Neda Tiraieyari, Institute for Social Science Studies, University Putra Malaysia, Malaysia 
program for Malaysia. A better understanding of extension workers' attitude on sustainable agriculture would help managers to understand if extension workers have been oriented themselves to carry out the task. Extension workers need to acquire positive attitude on SAP to influence farmers' adoption. According to Udoto and Flowers (2001) overall positive attitude of the benefits of sustainable agricultural practices to the environment may serve as a major influence for extension workers to transfer sustainable agriculture. Hence the first step to identify major obstacles to adoption of sustainable agricultural practices in Malaysia is to examine extension services to find out to what extent the extension workers acquired positive attitudes on sustainable agriculture? Past researches have been conducted to determine extension workers' attitude towards SAP (Chizari et al., 1999; Minarovic and Mueller, 2000; Straquadine, 1997; Allahyari et al., 2008; Allahyari, 2008; Udoto and Flowers, 2001; Williams and Wise, 1997). Scholars argued that generating desirable change in the attitude of extension workers at first step can be used as a foundation for extension workers to transfer SAP to the farmers. However little is known about Malaysian extension workers' attitude towards SAP. Hence this study aims to work with Malaysian extension workers at the DOA whom directly dealing with farmers.

The purpose of this study was to determine attitudes of extension workers towards SAP concepts. The specific objectives included:

- Determine extension workers' attitude towards production efficiency of SAP

- Determine extension workers' attitude towards economic viability of SAP

- Determine extension workers' attitude towards environmental sustainability of SAP

- Determine extension workers' attitude towards social responsibility of SAP

- Determine if diffrences exist in Malaysian extension workers' attitudes on SAP concepts when examined by level of education and years of working experiences

\section{MATERIALS AND METHODS}

The study employed a descriptive research design. Participants were selected from peninsular Malaysia who worked at the Department of Agriculture (DoA) including extension workers and supervisors. The total of 400 extension workers was selected randomly from west Malaysia. The instrument was adopted from previous studies conducted by Conner et al. (2004) and Chen (2003) with some modification. The questionnaire contained 19 statements related to four areas of the sustainable agriculture; production efficiency, economic viability, environmental sustainability and social responsibility.

The questionnaire was translated into Bahasa Malaysia by an expert. Before the survey, the instrument checked for content and face validity by panel of experts. The questionnaire reliability was estimated by calculating Chronbach's alpha. Respondent were asked to rate items using a semantic differential scale from 1 strongly disagree to 10 strongly agree. According to Allen and Rao (2000), in an empirical review of several scale types, a 10-point measurement scale is preferred to the five-point or sevenpoint likert scale. First the wider distribution of scores around the mean gives more discriminating power. The second reason is that, it is easier to establish covariance between two variables with grater dispersion around their means. Pallant (2007) also contended that the 10-piont scale gives respondents a wider range of possible scores and increase the statistical analysis available to respondents by arranging a number from 1 to 10 . Collected data were analyzed using the SPSS for Windows (version 20.0). Descriptive statistic including the mean and standard deviation were used to achieve objectives of the study. The one-way ANOVA, were also used to compare the effect of education and working experiences on extension workers 'attitude towards SAP.

\section{RESULTS}

Table 1 lists the Mean and Standard Deviation for the production efficiency statements. Among the statements used for assessment of production efficiency, the statement "Technology should be used as best as possible to increase efficiency of Agricultural production" had the highest mean with $8.63(\mathrm{SD}=1.34)$.

The overall mean of the respondents on production efficiency were divided into three levels for reporting purposes: (1.00-3.99 = low, 4.00-6.99 moderate, 7.00$10.00=$ high). Based on interpret scale, majority of extension workers, $89.8 \%(n=359)$ had high level of attitude on production efficiency. $10 \%(\mathrm{n}=41)$ of respondents reported moderate level of attitude on production efficiency (Table 2 ).

Table 3 includes the data for the economic viability statements. Statement "Farming is first and foremost a business like any other business"had the highest mean $8.95(\mathrm{SD}=1.39)$ among the statement. The overall mean of the respondents on economic viability were divided into three levels: 1.00-3.99 = low, 4.00-6.99 moderate, $7.00-10.00=$ high. Based on interpret scale, $76.5 \%(\mathrm{n}=$ 306) extension workers had high level of attitude on economic viability. $23.3 \%(n=93)$ of respondents reported moderate level of attitude on economic viability and only one extension workers reported had low attitude on economic viability (Table 4). 
Neda Tiraieyari et al. / American Journal of Environmental Science 9 (1): 33-37, 2013

Table 1. Mean and Standard Deviation for extension workers' attitude towards production efficiency

\begin{tabular}{lll}
\hline Production efficiency statements & Mean & SD \\
\hline $\begin{array}{l}\text { Production, processing and marketing of } \\
\text { agricultural products is best done at the local level }\end{array}$ & 8.21 & 1.39 \\
$\begin{array}{l}\text { Technology should be used as best as possible } \\
\text { to increase efficiency of Agricultural production }\end{array}$ & 8.63 & 1.34 \\
$\begin{array}{l}\text { Meeting food needs with fewer farmers is a } \\
\text { positive outcome of technological progress }\end{array}$ & 8.29 & 1.56 \\
\hline
\end{tabular}

Table 2. Level of extension workers' attitude towards Production efficiency

\begin{tabular}{lcccr}
\hline Level & Frequency & Percent & Valid (\%) & Cumulative (\%) \\
\hline Moderate & 41 & 10.3 & 10.3 & 10.3 \\
High & 359 & 89.8 & 89.8 & 100.0 \\
Total & 400 & 100.0 & 100.0 & \\
\hline
\end{tabular}

Table 3. Mean and Standard Deviation for extension workers' attitude towards economic viability

\begin{tabular}{lll}
\hline Economic Viability Statements & Mean & SD \\
\hline $\begin{array}{l}\text { The primary goal of farmers should be } \\
\text { to maximize the productivity, efficiency } \\
\text { and profitability of their farms. }\end{array}$ & 8.46 & 1.47 \\
$\begin{array}{l}\text { The successful farmer is one who earns } \\
\text { enough from farming to enjoy a } \\
\text { good standard of living }\end{array}$ & 7.85 & 1.85 \\
$\begin{array}{l}\text { Small to medium-size farmers } \\
\text { can best serve agriculture needs }\end{array}$ & 6.81 & 2.01 \\
$\begin{array}{l}\text { Farmers should farm only as } \\
\text { much land as they can personally care for }\end{array}$ & 7.48 & 1.97 \\
$\begin{array}{l}\text { The amount of farmland owned by an } \\
\text { individual/corporation should be limited in } \\
\text { order to encourage land ownership by as } \\
\text { many people as possible }\end{array}$ & 6.66 & 2.37 \\
$\begin{array}{l}\text { Farming is first and foremost a } \\
\text { business like any other business }\end{array}$ & 8.95 & 1.39 \\
\hline
\end{tabular}

Table 4. Level of extension workers' attitude towards economic viability

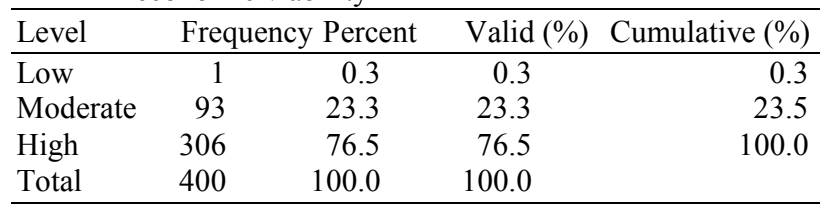

Table 5 shows the Mean and Standard Deviation for the Environmental sustainability of SAP. Among the statements used for assessment of production efficiency, the statement "Soil and water are the sources of all life and should therefore be strictly conserved" had the highest mean with 9.33( $\mathrm{SD}=1.13)$.

The overall mean of the respondents on Environmental sustainability were divided into three levels for reporting purposes: (1.00-3.99 = low, 4.006.99 moderate, $7.00-10.00=$ high $)$.
Table 5. Mean and standard deviation for extension workers' attitude towards Environmental sustainability

\begin{tabular}{lll}
\hline Environmental sustainability statements & Mean & SD \\
\hline $\begin{array}{l}\text { Soil and water are the sources of all } \\
\text { life and should therefore be strictly conserved }\end{array}$ & 9.33 & 1.13 \\
$\begin{array}{l}\text { Farms should be specialized in one or } \\
\text { at most a few crops }\end{array}$ & 7.44 & 2.24 \\
$\begin{array}{l}\text { The key to agriculture's future success } \\
\text { lies in learning to imitate natural ecosystems and } \\
\text { farm in harmony with nature. }\end{array}$ & 8.53 & 1.46 \\
$\begin{array}{l}\text { Modern agriculture is a major cause of } \\
\text { ecological problems and must be greatly modified } \\
\text { to become ecologically sound. }\end{array}$ & 7.82 & 1.87 \\
$\begin{array}{l}\text { Farmers should use primarily natural } \\
\text { fertilizers/production methods such as manure, crop } \\
\text { rotations, compost and biological pest control }\end{array}$ & 8.94 & 1.10 \\
$\begin{array}{l}\text { Farmland should be farmed so as to protect } \\
\text { the long-term productive capacity of the land, } \\
\text { even if this means lower production and profits }\end{array}$ & 8.17 & 1.59 \\
$\begin{array}{l}\text { Modern agriculture is a major cause of ecological } \\
\text { problems and must be greatly modified to } \\
\text { become ecologically sound }\end{array}$ & 7.65 & 1.98 \\
\hline
\end{tabular}

Table 6. Level of extension workers' attitude towards environmental sustainability

\begin{tabular}{lllll}
\hline Level & Frequency & Percent & Valid (\%) & Cumulative (\%) \\
\hline Moderate & 57 & 14.3 & 14.3 & 14.3 \\
High & 343 & 85.8 & 85.8 & 100.0 \\
Total & 400 & 100.0 & 100.0 & \\
\hline
\end{tabular}

Table 7. Mean and standard deviation for extension workers' attitude towards social responsibility

Environmental sustainability statements $\quad$ Mean $\quad$ SD

\begin{tabular}{lll} 
Agricultural extension programs & Mean & SD \\
\hline
\end{tabular}

should teach farmers about the interrelationships

among the environment, agriculture and people

An important responsibility of agricultural

$8.75 \quad 1.25$

extension programs is to develop future leaders for the

agricultural industry and communities rural in Malaysia

$\begin{array}{lll}\text { I believe our farmers have a good understanding } & 8.16 & 1.62\end{array}$

of the interrelationships among the

environment, agriculture and people

Table 8. Level of extension workers' attitude towards social responsibility

\begin{tabular}{lcccc}
\hline Level & Frequency & Percent & Valid (\%) & Cumulative (\%) \\
\hline Moderate & 31 & 7.8 & 7.8 & 7.8 \\
High & 369 & 92.3 & 92.3 & 100.0 \\
Total & 400 & 100.0 & 100.0 & \\
\hline
\end{tabular}

Based on interpret scale, majority of extension workers, $85.8 \%(\mathrm{n}=343)$ had high level of attitude on Environmental sustainability. $14.3 \% \quad(\mathrm{n}=57)$ of respondents reported moderate level of attitude on Environmental sustainability (Table 6).

Extension worker were asked a series of questions on their attitude toward social responsibility. 
Neda Tiraieyari et al. / American Journal of Environmental Science 9 (1): 33-37, 2013

Table 9. Extension Workers' Attitudes on SAP Concepts When Examined By level of education

\begin{tabular}{|c|c|c|c|c|c|c|}
\hline & \multicolumn{6}{|l|}{ ANOVA } \\
\hline & Sum of Squares & Df & Mean & Square & $\mathrm{F}$ & Sig. \\
\hline \multirow[t]{3}{*}{ Overall Attitude } & Between Groups & 2.64 & 3 & 0.881 & 1.010 & 0.388 \\
\hline & Within Groups & 345.58 & 396 & 0.873 & & \\
\hline & Total & 348.22 & 399 & & & \\
\hline \multirow[t]{3}{*}{ Economic viability } & Between Groups & 6.77 & 3 & 2.258 & 1.467 & 0.223 \\
\hline & Within Groups & 609.56 & 396 & 1.539 & & \\
\hline & Total & 616.33 & 399 & & & \\
\hline \multirow[t]{3}{*}{ Environment sustainability } & Between Groups & 2.10 & 3 & 0.702 & 0.593 & 0.620 \\
\hline & Within Groups & 468.96 & 396 & 1.184 & & \\
\hline & Total & 471.06 & 399 & & & \\
\hline \multirow[t]{3}{*}{ Production efficiency } & Between Groups & 5.20 & 3 & 1.735 & 1.480 & 0.220 \\
\hline & Within Groups & 464.38 & 396 & 1.173 & & \\
\hline & Total & 469.59 & 399 & & & \\
\hline \multirow[t]{3}{*}{ Social responsibility } & Between Groups & 0.86 & 3 & 0.289 & 0.201 & 0.896 \\
\hline & Within Groups & 571.08 & 396 & 1.442 & & \\
\hline & Total & 571.95 & 399 & & & \\
\hline
\end{tabular}

Table 10. Extension Workers' Attitudes on SAP concepts when examined by Years of working experiences

\begin{tabular}{|c|c|c|c|c|c|c|}
\hline & \multicolumn{6}{|l|}{ ANOVA } \\
\hline & Sum of Squares & $\mathrm{df}$ & Mean & Square & $\mathrm{F}$ & Sig. \\
\hline \multirow[t]{3}{*}{ Overall Attitude } & Between Groups & 4.89 & 3 & 1.630 & 1.880 & 0.132 \\
\hline & Within Groups & 343.33 & 396 & 0.867 & & \\
\hline & Total & 348.22 & 399 & & & \\
\hline \multirow[t]{3}{*}{ Economic viability } & Between Groups & 1.74 & 3 & 0.583 & 0.494 & 0.687 \\
\hline & Within Groups & 467.84 & 396 & 1.181 & & \\
\hline & Total & 469.59 & 399 & & & \\
\hline \multirow[t]{3}{*}{ Environment sustainability } & Between Groups & 6.24 & 3 & 2.083 & 1.77 & 0.151 \\
\hline & Within Groups & 464.81 & 396 & 1.174 & & \\
\hline & Total & 471.06 & 399 & & & \\
\hline \multirow[t]{3}{*}{ Production efficiency } & Between Groups & 3.63 & 3 & 1.213 & 1.09 & 0.351 \\
\hline & Within Groups & 439.01 & 396 & 1.109 & & \\
\hline & Total & 442.64 & 399 & & & \\
\hline \multirow[t]{3}{*}{ Social responsibility } & Between Groups & 5.78 & 3 & 1.927 & 1.34 & 0.259 \\
\hline & Within Groups & 566.17 & 396 & 1.430 & & \\
\hline & Total & 571.95 & 399 & & & \\
\hline
\end{tabular}

Table 7 presents mean and standard deviation for extension workers' attitude towards social responsibility (objective 4). Among the statements used for assessment of social responsibility, the statement "Agricultural extension programs should teach farmers about the interrelationships among the environment, agriculture and people" had the highest mean with $8.77(\mathrm{SD}=1.18)$.

The overall mean of the respondents for attitude towards social responsibility were divided into three levels: $1.00-$ $3.99=$ low, 4.00-6.99 moderate, 7.00-0.00 = high. Based on interpret scale, $92.3 \%(n=369)$ of extension workers had rated high on attitude towards social responsibility while $7.8 \%(\mathrm{n}=31)$ of extension workers had rated moderate and non rated low (Table 8).

A one-way between-groups analysis of variance was performed to compare the effect of level of education and year of working experiences on attitude of extension workers on SAP. Preliminary assumption testing was conducted to check for normality and homogeneity of variance with no serious violations noted. There is no singnificant diffrences exist in Malaysian extension workers' attitudes on SAP concepts when examined by level of education and years of working experiences (Table 9 and 10).

\section{DISCUSSION}

The main purpose of this study was to determine attitudes of extension workers towards SAP concepts and results revealed that extension workers attitudes towarsd dimension of SAP is favorable. This finding confirms the results of previous research (Chizari et al., 1999; Minarovic and Mueller, 2000; Straquadine, 1997; 
Allahyari et al., 2008; Allahyari, 2008; Udoto and Flowers, 2001; Williams and Wise, 1997). Among four dimensions of SAP namley; production efficency, social responsibility, environmnetal sustainability and economic viability, extension workers ranked social responsibility as hightest rank folowed by production efficency, economic viability and environmnetal sustainability. In addition based on the results of ANOVA test, level of education and working experince of extension workers didn't effect on their attitude towards dimension of SAP.

\section{CONCLUSION}

Although sustainable agriculture is relatively new in Malaysia, extension workers in west Malaysia indicated that they have positive attitude on SAP. However in order to gain a fuller understanding of extension workers' attitude on SAP concepts it is recommended further data collection could be undertaken. Indeed future research is needed to determine if this finding hold true for other extension workers at the DOA in east Malaysia. More research needs to be conducted in other agricultural agencies in Malaysia to investigate extension workers' attitudes on SAP concepts.

\section{ACKNOWLEDGMENT}

The researcher wish to thanks the Research Management Center (RMC) to grant this study.

\section{REFERENCES}

Agunga, R.A., 1995. What ohio extention agents say about sustainable agriculture. J. Sustain. Agric., 5: 169-187. DOI: 10.1300/J064v05n03_13

Allahyari, M.S., 2008. Extensionists attitude toward sustainable agriculture in Iran. J. Applied Sci., 8: 3761-3763.

Allahyari, M.S., M. Chizari and M. Homaee, 2008. Perceptions of iranian agricult ural extension professionals toward sustainable agriculture concepts. J. Agric. Social Sci., 4: 101-106.

Allen, D.R. and T.R. Rao, 2000. Analysis of Customer Satisfaction Data: A Comprehensive Guide to Multivariate Statistic Analysis in Customer Satisfaction, Loyalty and Service Quality Research. 1st Edn., ASQ Press, ISBN-10: 0873894537, pp: 243.
Barrow, C.J., C.N. W.eng and T. Masron, 2009. Issues and challenges of sustainable agriculture in the cameron highlands. Malaysian J. Environ. Manage., 10: 89-114.

Chen, H.Y., 2003. Assessing Faculty Perceptions of the Ecological Paradigm of the College of Food, Agricultural and Environmental Sciences. 1st Edn., Ohio State University, Columbus, pp: 210.

Chizari, M., J.R. Linder and M. Zoghie, 1999. Perception of extension agents regarding sustainable agriculture in the Khorasan Province, Iran. J. Int. Agric. Extension Educ.

Conner, J.J., B. Swan and J.A. Brousseau, 2004. Perception of Lithuanian agriculture teacher towards the ecological paradigm. Proceeding of the 20th Annual Conference, (AC' 04), Dublin.

Liaghati, H., H. Veisi, H. Hematyer and F. Ahmadzadeh, 2008. Assessing the student's attitudes towards sustainable agriculture. Am. Eurasian J. Agric. Environ. Sci., 3: 227-232.

Minarovic, R.E. and J.P. Mueller, 2000. North carolina cooperative extension service professionals' attitudes toward sustainable agriculture. J. Extension.

Pallant, J., 2007. SPSS Survival Manual: A Step by Step Guide to Data Analysis using SPSS for Windows. 3rd Edn., Open University Press, Maidenhead, ISBN-10: 9780335223664, pp: 352.

SARE, 2003. Exploring Sustainability in Agriculture. 1st Edn., Sustainable Agriculture Research and Education (SARE) Program, Washington, D.C., pp: 13.

Straquadine, G.S., 1997. An assessment of the agricultural education teachers' sustainable agriculture understanding and instructional materials use. Southern Western Regions Agric. Educ. Res.

Tiraieyari, N. and J. Uli, 2011. Sustainable agriculture in Malaysia: Implication for extension workers. J. Am. Sci., 7: 179-182.

Udoto, M. and J. Flowers, 2001. Perceptions of agricultural education teachers toward sustainable agricultural practices. Proceedings of the 28th Annual National Agricultural Education Research Conferences, Dec. 12-12, pp: 443-444.

Williams, D.L. and K.L. Wise, 1997. Perceptions of Iowa secondary school agricultural education teachers and students regarding sustainable agriculture. J. Agric. Educ., 38: 15-20.

Williams, D.L., 2000. Students' knowledge of and expected impact from sustainable agriculture. J. Agric. Educ., 41: 19-24. 